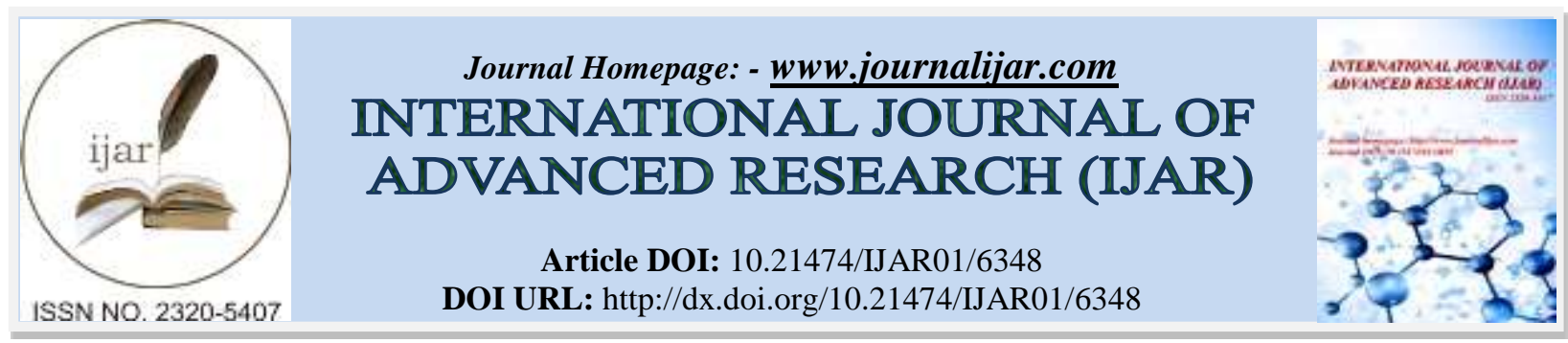

RESEARCH ARTICLE

\title{
TRADITIONAL LOCAL ADAPTATION STRATEGIES OF WOMEN TO THE 2012 FLOODING IN COMMUNITIES IN RIVERS AND BAYELSA STATES, NIGERIA.
}

Osuji, Enyioma Ruby. Prof. Steve Okodudu and Dr. S. Joab-Peterside. Department of Sociology, University of Port Harcourt. Nigeria.

\section{Manuscript Info}

Manuscript History

Received: 19 November 2017

Final Accepted: 21 December 2017

Published: January 2018

\begin{abstract}
In the face of their vulnerability, women have clearly demonstrated resilience in managing disasters using divers coping strategies. The study investigates the traditional local adaptation strategies of women to the 2012 flood in communities in Rivers and Bayelsa state. The aim is to identify those coping strategies adopted by women during the 2012 flood. The study area covered Ukaki, Zarama-Epie and Igbogene in Yenegoa Local Government Council of Bayelsa State, Edoha, Okporowo and Oshika in Ahoada East and Okaki, Odawu and Isua in Ahoada West Local Government Councils of Rivers State, all in the Niger Delta of Nigeria. The study adopted the cross sectional survey design. The sample size for this study is 400 and this was determined using the Taro Yamane formula. The study adopted the multi-stage sampling technique. First the three (3) Local Government Councils directly affected by the flood were selected while purposive sampling technique was adopted to select the communities that were directly affected by the flood disaster in these Local Government Councils. However, to select the 400 respondents (women), the systematic random sampling method was adopted. The study revealed that planting of flood resistant crops and trees, Traditional storage system, Construction of make-shift platforms and bridges and the use of Indigenous weather warning systems were some of the traditional adaptation coping strategies adopted by women in dealing with the flood disaster in the study area.
\end{abstract}

Copy Right, IJAR, 2018,. All rights reserved.

\section{Introduction:-}

It is a good starting point to state that natural disaster concerns have consistently remained a topical issue in global, regional, national policy and academic discourses. This level of concern is associated with the magnitude of negative consequences that come with natural disasters. According to Alani (2012), there have been natural and man-made disasters all over the world. These disasters cause a lot of devastation on lives and resources. He further observed that within the early years of the 21 st century alone, incidents of chemical spillages, explosions, earthquakes, landslides, thunderstorms, hurricanes, infernos, tornadoes, floods, wild fires, tsunamis, volcanic eruptions, dam collapses, violent uprisings and massacres have been reported with various degrees of destruction around the world. Institutional and individual observers of these incidents agreed that there has been an increase in these occurrences over the past decades (Askew, 2009 and Levine, 2013). 
While the experiences of disasters vary from country to country, there are grim indicators that no State on earth is insulated from it (Mumuni, 2013). For developing countries such as Nigeria, the weakness of State infrastructures, absence of appropriate legal and policy frameworks and sometimes inadequate resources, create situations of vulnerability during disaster scenarios. This is why Fadahunsi (2013) opined that the prevention, management and reduction of disasters are therefore a huge challenge for a country like Nigeria. Countries throughout the world have recognized the need to formulate a clear regulatory agenda aimed at the prevention, management and reduction of disasters. A manifestation of this was the Hyogo Framework for Action (HFA) 2005-2015 titled "Building the Resilience of Nations and Communities to Disasters: A Global strategy to Reduce Disaster Risks". The HFA is the first plan to explain, describe and detail the work that is required from different sectors and actors to reduce disaster losses. It was developed and agreed on with the many partners needed to reduce disaster risk - governments, international agencies, disaster experts and many others - bringing them into a common system of coordination.

There is evidence to suggest that in many countries there has been an increase in the risk of natural disasters due to environmental degradation (World Bank, 2013). Natural disasters are complex and multifaceted events resulting from mismanaged and unmanaged risks that reflect current conditions and historical factors (Fadahunsi, 2013). A disaster is said to take place precisely because the losses originated by a given event overwhelm the capacity of a population (local, regional or national) to respond and recover from it. Risks associated with natural disasters emerge from the interaction between a natural hazard - the external risk factor - and vulnerability - the internal risk factor.

While natural disasters leave behind long term negative consequences, they can also have severe short term impacts on public finances: loss of revenue, rise in expenditure, and indirectly through publicly owned utilities, with longer term consequences for economic growth, development and poverty reduction (Mumuni, 2013). A World Bank report estimated that between 1990 - 2000, the economic loss caused by natural disasters represented 2 to 15 percent GDP of an exposed country (World Bank, 2013). The link between high exposure to disaster risk and poverty is now widely accepted. Environmental degradation, migration, lack of land rights, and lack of access to basic services are just some of the factors which have a direct adverse effect on the poor and also exacerbate the risk of, or difficulty in recovering from natural hazards. About $98 \%$ of those killed and affected by natural disaster are from developing countries, and it is estimated that by 2025 , over half of all people living in developing countries will be highly vulnerable to floods and storms (Tearfund, 2010).

Natural disasters typically affect the poorer parts of the world which are more vulnerable to their negative impacts. There is also growing concern that climate change has already, or will, increase the severity and frequency of some forms of natural hazard. At the same time there is a discernible trend in both policy discussion and in the research literature away from seeing natural catastrophic events as literally uncontrollable 'disasters' to recognizing them in part as a product of more complex socio-economic processes, including vulnerability and the collapse of livelihoods (Askew, 2009; Alani, 2012; Levine, 2013).

\section{Statement of the problem:-}

Women have been said to be custodians of tradition and possess indigenous knowledge on environmental conservation. Sadly, women have been the most vulnerable to environmental natural disasters like flooding (Agomoh, 2017). Tragedies associated with flood disasters in Nigeria have significant effects on the people, city infrastructure and urban governance. In recent time most city residents felt the impacts of floods directly or indirectly (Odufuwa, Adedeji, Oladesu \& Bongwa, 2012). For developing countries such as Nigeria, the weakness of State infrastructures, absence of appropriate legal and policy frameworks and sometimes inadequate resources, particularly creates situations of vulnerabilities during disaster scenarios. It is in this regard that Fadahunsi (2013) opined that the prevention, management and reduction of disasters are therefore a huge challenge for a country like Nigeria.

Yasui (2007), Norris (2008) and Olukolade (2012), maintain that primarily losses can be high in rural areas, where most of the damage is sustained by crops, livestock and the agricultural infrastructure, such as irrigation system, levees, walls and fences. According to Norris (2008), flooding leads to large scale disruption of social and economic lives especially in rural areas where the principal occupational activity resides within the agricultural sector.

Enarson's (2001) study suggests a positive and negative occupational outcome especially for women during natural disasters. According to her, women's economic status is a critical indicator of women's vulnerability in disasters and 
their economic assets are key recovery resources during such periods. Though women's employment rates around the world are increasing, women also work in home-based jobs, producing goods and services in the informal-sector, and in subsistence and waged agriculture. Using the Red River Valley flood in the United States as her case study, she argued that two-thirds of women were employed, including 74\% of those with children under six. Most were employed in the service and retail sectors. Enarson (2001) found that women lost their work in the flood but also found new jobs as agencies expanded their goals and staff. Enarsons study focused on the Red River Valley flood in the United States, where there is the potential to create alternative jobs for women. However this is not the case in Rivers and Bayelsa states where majority of the women are in rural areas and are engaged in Agriculture. The possibility of good alternative jobs for women after the flood is slim.

The unequal impact of floods on women, compared to men, is not limited to natural disasters alone; rather, it also permeates everyday life and opportunities. The gender inequality resulted from the socially constructed norms, expectancies, values, roles and relations, which till today guide attitude and perceptions of gender roles. Men's stereotypical belief that women should continue to take charge of the domestic chores in the home domain, even in the face of overwhelming evidence that women have joined the workforce in thousands, has not ameliorated their sufferings ( Ugwu and Ugwu, 2013). Women are made more vulnerable than men because women have reduced access to education and are often excluded from disaster prevention and preparedness, including emergency intervention programme (Young, 2008). In a study on the Vulnerability to Flood Disaster in Kano State, Nabegu, (2014) clearly stated that Gender clearly played a role regarding the dead, as nearly twice as many females $72 \%$ as males $28 \%$ were dead, indicating that females are more vulnerable to flood than men. In addition to their physical weakness, the study showed that female might also be more exposed due to their traditional role of carrying out activities around the house. The enormous gender gap between the revealed vulnerability of females and males showed that women are in the likelihood of being killed by flood.

In the face of their vulnerability, women have clearly demonstrated their resilience in managing disasters using divers coping strategies. This study seeks to examine the traditional Local Adaptation Strategies of women to the 2012 flood incident in Rivers and Bayelsa states.

\section{Conceptual clarifications:- \\ Coping Strategies:-}

Coping strategies are measures used to reduce or palliate stressful events like disasters. According to Wisner et al (2004), coping strategies can be complex, they can either be preventive or impact-minimizing. As a preventive measure, it allows people or individuals to make choices so that events that are dangerous will not affect them. In doing so, they may choose to live in safer residential locations or to avoid dangerous places. Again for it to be impact- minimizing, the strategies help to palliate or relieve individuals from loss or pain caused by an event. For instance, it suggests that individuals would have access to a minimum level of food, shelter and physical security, in order for them to be less vulnerable in time of disaster (Wisner et al, 2004).

Coping strategies can be in different levels. It can be on individual level(household), community level(neighbourhood) or institutional level(city-wide or beyond). For individuals, coping strategies function at the household level, as individuals cooperate to make things work. At the community level, members work together to improve their resilience. Beyond the household, community-based organizations, religious organizations etc. organize themselves and work together to improve their lot. The NGOs or even the local governments operate at the institutional level coping strategies (Huraera et al, 2010). Hug and Ried (2007), quipped that external agencies must understand and build on the existing local coping strategies.

Tylor, Karmach, \& Shiffman, (2004), quipped that victims use prayer as a means of coping during tragedies or disasters. Kwilecki (2004), added that religion is used as a therapy for coping with stress, this includes prayers which deal with people`s emotions. Malik (2010), argued that families who have some form of education, see the need to work hard to retain their original status as important. To them, depending on anyone, is not acceptable. They make good use of the support from donor agencies and the government, to rebuild their broken down homes. They also use the support to get themselves back to track.

According to Wosu (2007), "securing livelihoods, the means used to maintain and sustain life, is essential to enable internally displaced persons (IDPs) working in groups or alone to cope with displacement". He added that as the IDPs search for livelihoods, they consider the available resources, look for ways to mobilize and access the 
resources while prioritizing their goals. The resources available for the IDPs to take advantage of include, household assets, social, cultural and economic resources, and social networks (Wosu, 2007).

Livelihood strategies are those tasks that the IDPs use to obtain a means of living. Networking is also an implement used by displaced women to access income, food and form solidarity with other women (Wosu, 2007). Wamsler (2007), UNFCCC (2004), Douglas (2008), stated that as a strategy to cope with flood disasters, furnitures are raised up or are built to be higher. This is to avoid the water touching people. Waterways are also blocked while outlets are created to re-channel the water. Again, water resistant materials are used to rebuild the broken down houses. Sandbags are also laid around the neighbourhoods and houses to help people move around. Furthermore, the urban poor develop social support network as a coping strategy. This can be in form of financial help, emotional support, shelter etc. from extended family members, friends, government or other social groups (Wisner, 2004; Wamsler, 2007).

\section{Causes of Flood:-}

A variety of climate and non-climate processes influence flood. In other words, there are natural and man-made causes of flood. Natural causes include heavy or torrential rainfall, rainstorms, tidal waves, ocean surge, ice/snow melt etc. while man-made causes of flood include dam burst or dam overflow, burst water pipes from the main source, blockage of drainage systems among others. Rivers overflow their banks to cause flood. It happens when water upstream is more than normal which overflows downstream to adjacent low-lying areas (flood plains) and inundates the area (UNICEF, 2010).

When there are more rains than the drainage systems can take, flood occurs. Studies by UNICEF confirms that sea water can be carried by strong winds and hurricanes to dry coastal lands and cause flooding. Too much water in the dam which puts pressure on it can make the dam to collapse and overflow the area. More so, water can be released from the dam intentionally to prevent sudden breakage. This also can cause flood. In many cold regions, after the winter, ice that formed from the snow fall, starts melting with the rise in temperature, thereby causing flood. This is usually called "snowmelt flood".

Human activities increase both the severity and the frequency of floods: paving roads and parking lots reduces water infiltration into the soil, thus increasing the rate of runoffs into lakes and streams (Cunningham, Cunningham, 2006). They added that clearing of forests for agriculture and construction of buildings (houses), poorly constructed dams, also increase the volume and rate of water discharge after a storm and cause the area to be flooded.

From a socio-economic perspective, Oriola (2012) observed that various socio-cultural activities have promoted flooding in many of the Nigerian communities, which includes urban land use. As urban environments grow, especially in cities located on flat terrain and where drainage system is poor, flood is imminent even with little rain. This is especially so in developing countries like Nigeria where refuse disposal is indiscriminately done, which in turn blocks the drainages. These activities are characterized by stream or river channel encroachments and abuse, increased paved surface and poor solid waste disposal techniques, due to a high level of illiteracy, a low degree of community awareness, poor environmental education, ineffective town planning laws and poor environmental management. He argued that government, at various levels need to address these issues. He concluded that flood risk in the Ondo urban environment was a function of the following factors: Land-use pattern, refuse disposal habits, the nature of the surrounding buildings, distance of building from the course of the streams, rainfall amount and duration, the relief or the terrain, slope, gradient, and other stream basin parameters(Oriola, 2012).

In a study conducted by Laughlin and Kalma (2000), that led to the development of a methodology for flood risk mapping a regional weather data and local terrain analysis, it was discovered that seasonal rainfall that generate flooding conditions is also a function of changes in weather patterns. By extension, it was also found that the deviation of temperatures at individual sites could be predicted from a local terrain parameter which reflects the extent of cold air accumulations. Finally, the study describes the model and illustrates the regional wetland terrain effect with three-dimensional block diagrams of how high rainfall levels come into effect and their impact on flood disaster. Changes in weather patterns like global warming can cause flood. From this perspective therefore, it is the assumption that the conditions which lead to flood occur when the rainfall amount over a particular region is more than a certain amount, normal for that region. 
Durotoye (2013:23), elaborated on the four major sources of water that largely contribute to the inundation of the deltaic plains. These include:

1. The annual river peak-discharge of River Niger especially the "White Flood" in October and the "Black Flood" between December and March. The "Black Flood" discharge, which originates from the Niger's headwaters in Guinea generates freak episodes of high discharge during exceptionally high rain in wet years. The "White Flood" originates mostly from within the Nigerian catchment areas. It has a high suspended load of fine sand/silt and clay which are deposited to build the deltaic alluvial flood plains and levees. She observed that high peak discharges causes bank and levees failures as the stream burst their banks seasonally to create disastrous floods.

2. The role of heavy rainfall peaks;

3. Man induced floods through oil exploitations and explorations, and human interference with the courses of stream channels during various constructional works;

4. Tidal floods especially in the coastal areas and mangrove swamps. The tidal flooding by ocean water created the characteristics brackish water environment. Also ocean surges also generate stormy high tides resulting in destructive flood.

Similarly, Abams (2014), reported in his study of floods in Kiama (in Bayelsa State), Nigeria, located in the lower deltaic flood plain on River Nun that the annual flooding experienced are a consequence of the combined effect of the "White Flood" discharges and the heavy rains from tropical storms. The rainfall is up to 3250 $\mathrm{mm} / \mathrm{year}$, about $80 \%$ of which is received between June and October. Heavy torrential rains are known to fall continuously for several days (up to ten days at times). The rainwater collects over impermeable silty clay plains. Consequently, meandering rivers not only over flow their banks but are actively eroding them and causing bank failures. It is also important to note that the ground level of water table is virtually several metres above surface (up to $9 \mathrm{~m}$ ) rains, leaving little or no room for percolation into the ground.

\section{Socio- Economic Implications of Flood:-}

When the areas used for socio-economic activities are flooded, it has some negative impacts on the lives of people. Loss of livelihoods: Economic activities come to a halt when floods occur (APFM, 2013). Flooding affect production of goods and services, it disrupts agricultural productions. In other words people are not able to carry out their economic activities as a result of the flood which overtakes their farmlands. Hunters are not able to go for their game to mention but a few. Flood affects the agricultural sector. Flash flooding damages the produce or crops e.g. vegetables, fruit trees, rice and other crops including economic trees. This increases the risk of hunger especially to subsistence farmers and a huge loss to those who engage in commercial farming (Kolawole O, Olayemi A., Ajayi K., 2011). Destruction of crops, farmlands and livestock can cause long term food insecurity.

Kolawole et al (2011) quipped that hunger reduces labour output, which may lead to emotional or psychological havoc/dishevelment, thereby causing mental ill health. River pollution also affects aquaculture (fish) negatively, which leads to the reduction in food protein for individuals in the society (Kolawole et al, 2011). Again the quality of water is jeopardized or endangered by flood which leads to easy spread of water borne diseases. When flood water rises and covers the roads and bridges, it displaces the means of transportation, thereby disrupting the movement of people and goods. Furthermore, market places are not left out by the floods, as they are also submerged for weeks and even months. As a result of flood incidents, transport fares increase making it difficult for people to move about. It also causes delays in shifting of farm produce to the different markets thereby increasing demand and reducing the supply thereby causing artificial scarcity. When movement of goods and services is disrupted, markets shut down because it has been submerged and washed away by flood, hunger is imminent and poverty is increased (Etuonovbe, 2011).

Educational institutions are not left out during floods. School premises are also submerged in the flood waters and as a result, schools are closed down for as long as the floods last. Some schools are relocated to neighbouring communities, till the flood recedes. During this time students stay at home and learning is disrupted. Again, some students whose schools were relocated may use distance as excuse not to go to school. Some drop out of school as a result of the closure or relocation of their schools, thereby increasing the rate of illiteracy and miscreants in the society.

Etuonovbe (2011), reiterated that flood also degrades the environment as much as it has some devastating effects on agriculture (farmlands, crops and animals).Ecosystem and biodiversity is lost because of flood disasters. Chemicals 
from industries can also affect crop yields after the flood thus reducing harvest and increasing hunger. Electric poles are pushed down causing power outage for a long period of time. Power outage slows down economic activities or shuts it down completely. Businesses that depend solely on power, resort to their generators which also pollutes the environment leading to climate change. In other words, flooding makes individuals, communities and nations poor as it breaks up services, causing erosion and causes chemical pollution. The damages caused by flood, takes a lot of energy, resources (finance), time etc. to put back in place. AFPM (2013), corroborates with other researchers on the fact that flood does a lot of damages to bridges, houses, industries etc. As a result, economic activities come to a standstill as the case may be. Damage to infrastructure, causes long-term impact e.g. the disruption of transport, communication and educational systems. Furthermore, the supply of electricity would also be disrupted making it difficult for people to carry on some activities that require power. Again, recurrent flooding as well as high cost of relief and recovery may discourage long-term investment by the private sector and the government alike.

\section{Study area:-}

The study area include Ukaki, Zarama-Epie and Igbogene in Yenegoa Local Government Council of Bayelsa State. Edoha, Okporowo and Oshika in Ahoada East and Okaki, Odawu and Isua in Ahoada West Local Government Councils of Rivers State. The Selected communities in Rivers and Bayelsa States are located in Ahoada East, Ahoada West and Yenegoa Local Government Councils, in the Niger Delta area of Nigeria. Niger Delta is the second largest delta in the world with a coastline spanning about 450 kilometres terminating at the Imo River entrance. The region spans over 20,000 square kilometres and it has been described as the largest wetland in Africa and among the three largest in the world. About 2,370 square kilometres of the region consist of rivers, creeks and estuaries and while stagnant swamp covers about 8600 square kilometres. The delta, with mangrove swamps spanning about one thousand, nine hundred $(1,900)$ square kilometres, has the largest mangrove swamps in Africa. The region falls within the tropical rain forest zone. The ecosystem of the area is highly diverse and supportive of numerous species of terrestrial and aquatic flora and fauna and human life. As opined by Iyayi (2004), it is the richest wetland in the world. The region is divided into four ecological zones namely coastal inland zone, mangrove swamp zone, freshwater zone and lowland rain forest zone. The region has emerged as one of the most ecologically sensitive regions in Nigeria. Resources (oil and gas) from the region are the main source of revenue for the Nigerian State, accounting for about $97 \%$ of the country's total export. According to Mmom and Pedro (2012), in terms of socio-economic development, the region could be described as being a "rich region with poor people.

\section{Research Methods:-}

This study adopted the cross sectional survey design. Cross sectional survey design involves the use of multiple survey methods. The total population of women in Ahoada East, Ahoada West and Yenegoa LGAs in Rivers state and Bayelsa state respectively is $\mathbf{3 7 2 , 2 2 8}$. The sample size for this study is 400 and this was determined using the Taro Yamane formula thus $\mathrm{n}=\left[\mathrm{N} / 1+\mathrm{N}(\mathrm{e})^{2}\right]$.

Table1:- Sample Size Determination

\begin{tabular}{|c|c|c|}
\hline Taro Yamane & $\begin{array}{l}\text { Ahoada East, Ahoada West and } \\
\text { Yenegoa LGAs }\end{array}$ & Sample \\
\hline \multirow{5}{*}{$n=\frac{\mathrm{N}}{1+\mathrm{N}(\mathrm{e})^{2}}$} & $\mathrm{~N}=372,228$ & \multirow[t]{5}{*}{732} \\
\hline & $(\mathrm{e})^{2}=.05 \times .05=0.0025$ & \\
\hline & $0.0025 \times 372,228=930.57$ & \\
\hline & $1+930.57=931.57$ & \\
\hline & $:-\mathrm{n}=372,228 \div 931.57=\mathbf{4 0 0}$ & \\
\hline
\end{tabular}

The study adopted the multi-stage sampling technique. First the three (3) LGAs directly affected by the 2012 flood were selected. The purposive sampling technique was adopted to select the communities that were directly affected by the 2012 flood disaster in these LGAs. However, to select the 400 respondents (women), the systematic random sampling method was adopted. In doing this, the first household in each affected community was randomly selected and thereafter every $10^{\text {th }}$ household was included in the study until the determined sample size was reached. Where there was no woman in a household, that household automatically fell out of the sampling frame and another household was chosen until the required sample was reached. 
Table 2:- Communities and population of women in the affected Local Government Area.

\begin{tabular}{|l|l|l|l|}
\hline State & Local Government Area & Communities & Number of Women \\
\hline Rivers & Ahoada-East & Edoha & \\
\hline & & Okporowo & 80,857 \\
\hline & & Oshika & \\
\hline & & & \\
\hline & Ahoada-West & Okaki & \\
\hline & & Odawu & 121,326 \\
\hline & & Isua & \\
\hline Bayelsa & & & \\
\hline & Yenogoa & Ukaki & 170,045 \\
\hline & & Zarama-Epie & \\
\hline & & Igbogene & $\mathbf{3 7 2 , 2 2 8}$ \\
\hline
\end{tabular}

\section{Results and discussion:-}

Data were obtained from the field through administered questionnaire. A total of 400 copies of the questionnaire were distributed to respondents within Ahoada East, Ahoada West and Yenegoa LGAs of Rivers and Bayelsa state respectively out of which 368 were duly completed and returned which represents $92 \%$ response rate.

Socio-demographic data of respondents:-

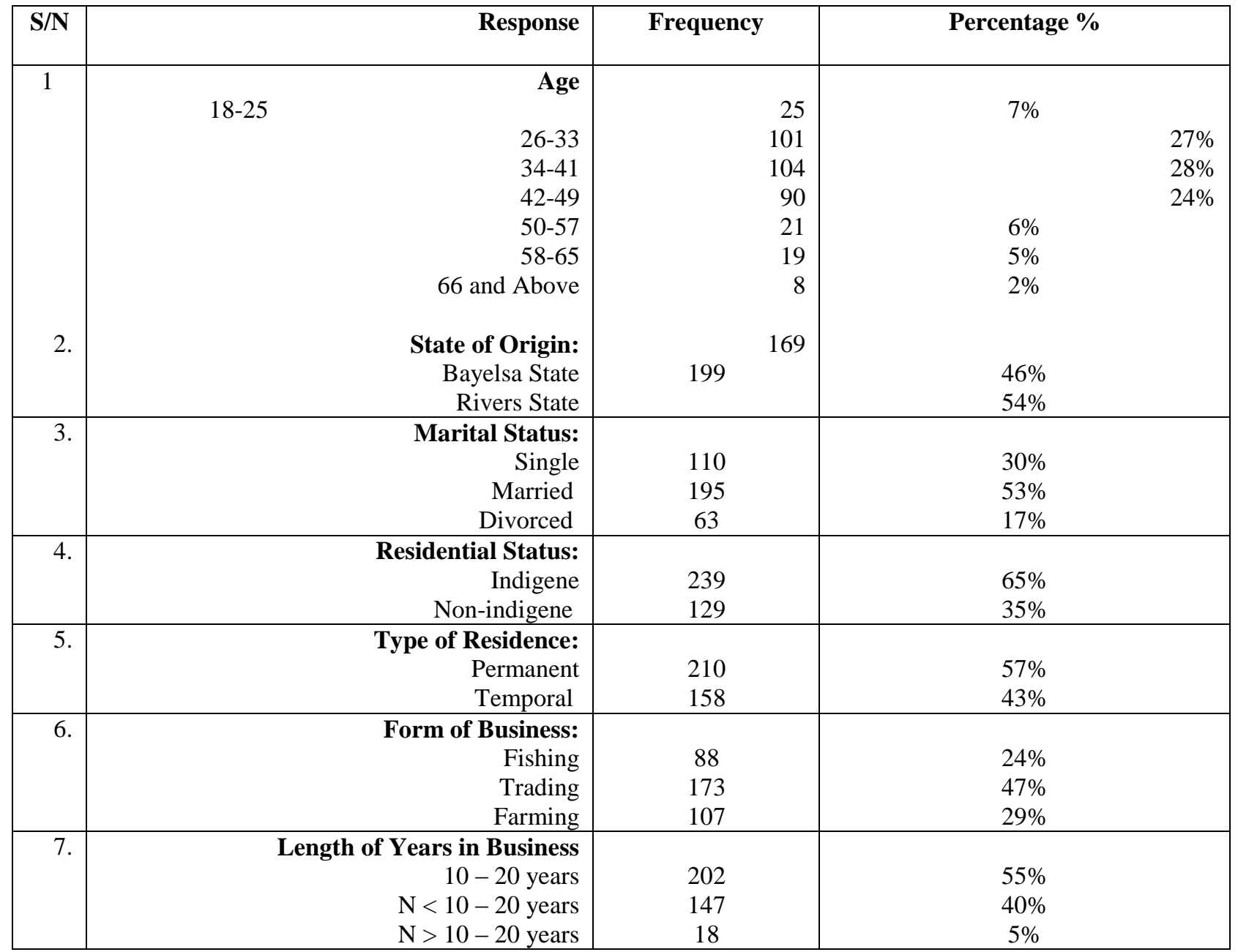


Table 3 showed information on the socio-demographic response of women in Rivers and Bayelsa states. Information on the age distribution of respondents in the study area as indicated on table 4.1 above, showed that some of the respondents at 104 (28\%) fall within the age cohort of 34-41 it was followed by $101(27 \%)$ of the respondents who fall within the age cohort of 26-33. It was closely followed by $90(24 \%)$ of the respondent that fall in the age cohort of $42-49$.

Traditional coping strategies adopted by women during and after the 2012 flood incident in Rivers and Bayelsa States:-

Table 3:-

\begin{tabular}{|c|c|c|c|}
\hline 1. & $\begin{array}{l}\text { Planting of flood resistant crops and trees. } \\
\text { Agree } \\
\text { Strongly agree } \\
\text { Disagree } \\
\text { Strongly disagree }\end{array}$ & $\begin{array}{c}241 \\
110 \\
14 \\
3 \\
368\end{array}$ & $\begin{array}{c}65 \\
30 \\
4 \\
1 \\
100\end{array}$ \\
\hline 2. & $\begin{array}{l}\text { Use of indigenous weather warning system. } \\
\text { Agree } \\
\text { Strongly agree } \\
\text { Disagree } \\
\text { Strongly disagree } \quad \\
\end{array}$ & $\begin{array}{c}231 \\
99 \\
26 \\
12 \\
\mathbf{3 6 8}\end{array}$ & $\begin{array}{c}63 \\
27 \\
7 \\
3 \\
\mathbf{1 0 0}\end{array}$ \\
\hline 3. & $\begin{array}{l}\text { Construction of make shift platforms and } \\
\text { bridges. } \\
\text { Agree } \\
\text { Strongly agree } \\
\text { Disagree } \\
\text { Strongly disagree } \quad \text { Total }\end{array}$ & $\begin{array}{c}28 \\
262 \\
68 \\
10 \\
\mathbf{3 6 8}\end{array}$ & $\begin{array}{c}8 \\
71 \\
18 \\
3 \\
100\end{array}$ \\
\hline 4. & $\begin{array}{l}\text { Creation of traditional storage systems. } \\
\text { Agree } \\
\text { Strongly agree } \\
\text { Disagree } \\
\text { Strongly disagree } \quad \\
\end{array}$ & $\begin{array}{c}291 \\
6 \\
64 \\
7 \\
\mathbf{3 6 8}\end{array}$ & $\begin{array}{c}79 \\
2 \\
17 \\
2 \\
\mathbf{1 0 0}\end{array}$ \\
\hline
\end{tabular}

Fig 1:- Flood resistant crops and trees

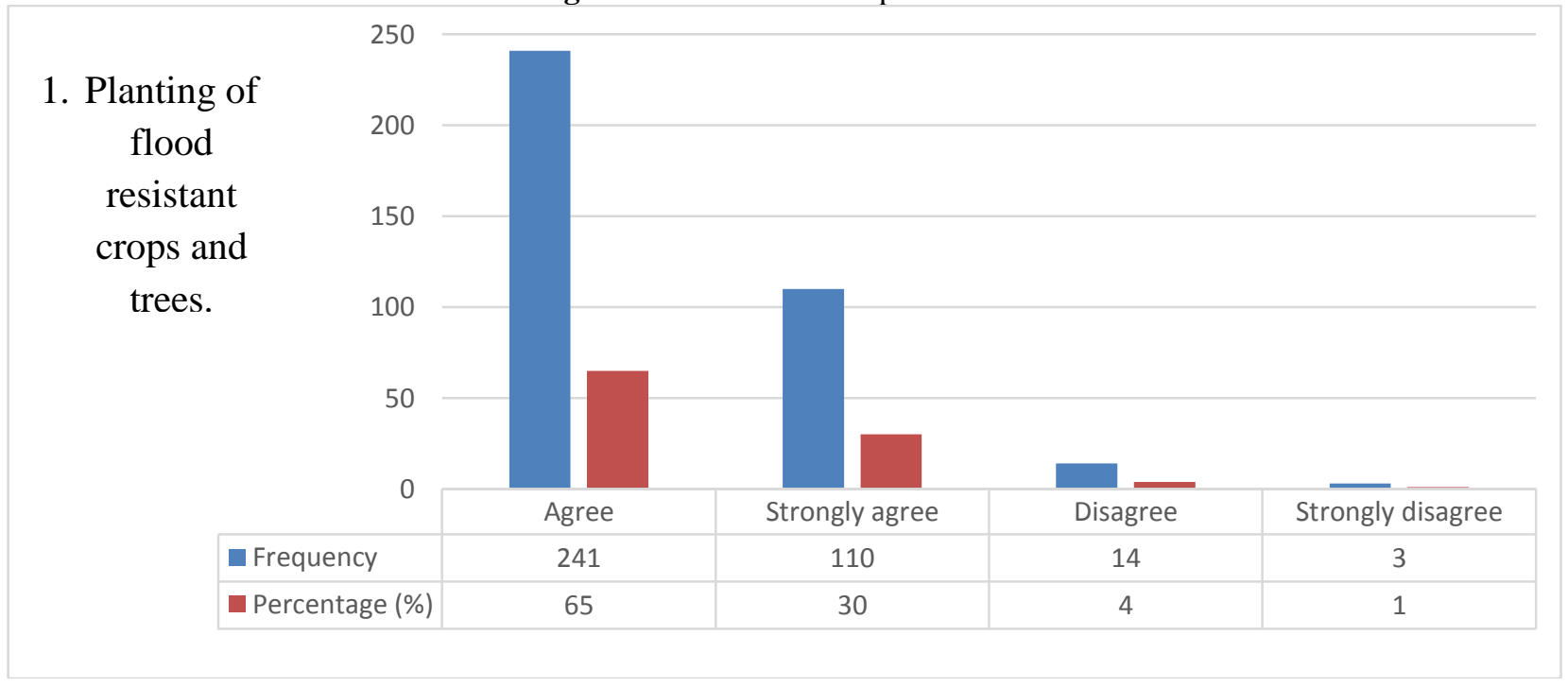


Fig 2:- Indigenous weather warning system

2. Use of indigenous weather warning system.

200

50

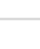

15

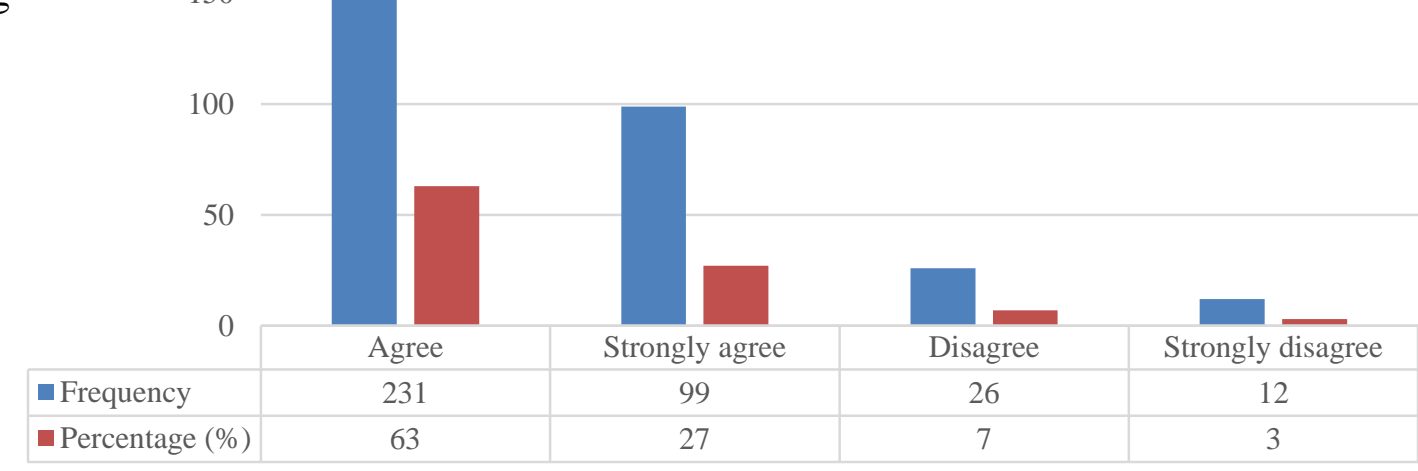

Fig 3:- Construction of make-shift platforms and bridges

\section{Construction} 300 of make-shift platforms and bridges.

200

250

50

(2)

- Frequency

- Percentage (\%)

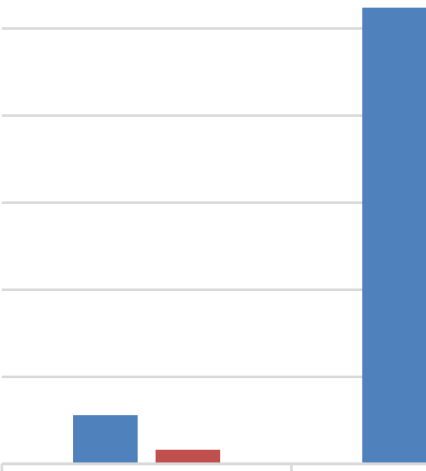

Agree

28
Strongly agree

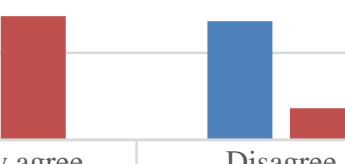
8 71

Fig 4:- Traditional storage system

4. Creation of traditional storage systems.

\section{0}

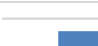


Information on the coping strategies adopted during and after the 2012 flood incidence showed that 241 (65\%) and $110(30 \%)$ of the respondents agreed and strongly agreed that they planted flood resistant crops and trees while 231 $(63 \%)$ and $99(27 \%)$ of the respondents agreed and strongly agreed that they made use of indigenous weather warming systems. Again, $262(71 \%)$ of the respondents strongly agreed that they constructed make shift platforms and bridges during the flood, while $291(79 \%)$ of the respondents agreed that they used traditional storage systems after the 2012 flood disaster.

Fig.5:- Making of mounds and high ridges.

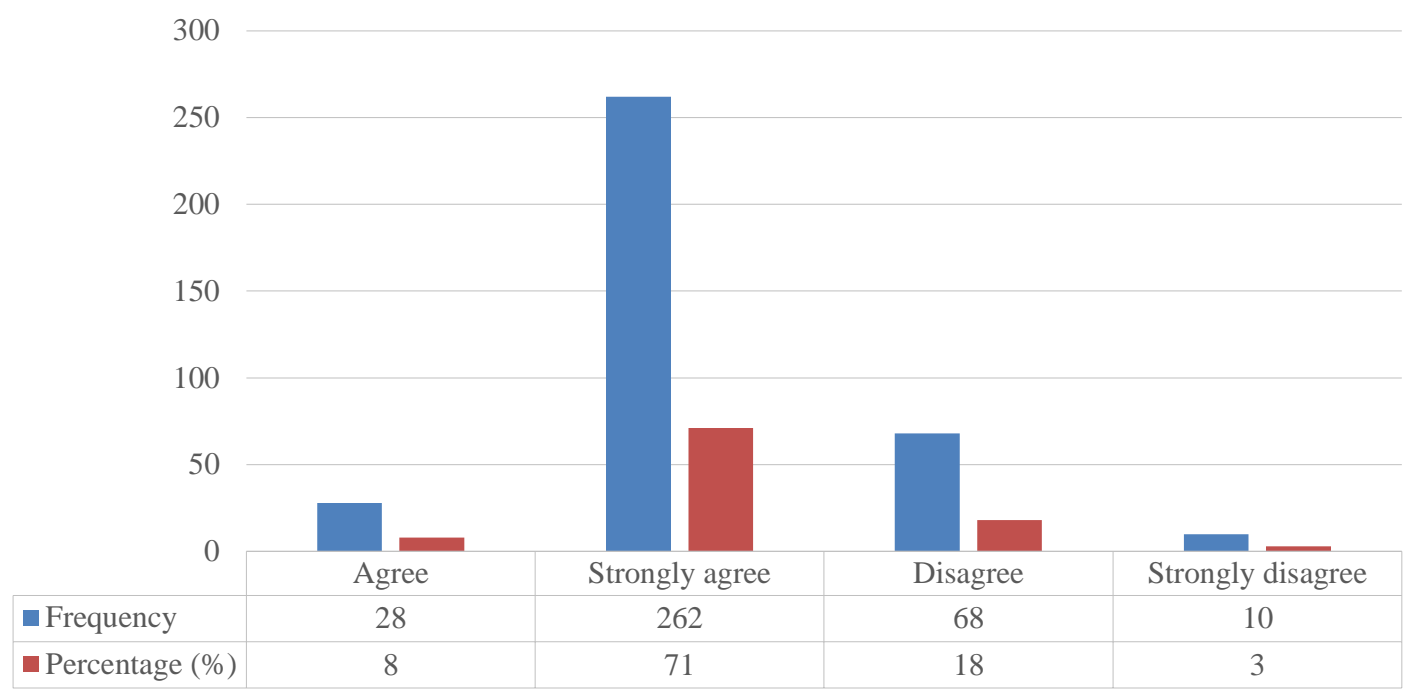

The information retrieved from respondents showed that $71 \%$ strongly agreed that they made mounds and high ridges before planting their crops after the flood disaster. This helps to save their crops from being destroyed by flood.

\section{Conclusion:-}

The method adopted by the study in its investigation of the relationship between flood and Traditional Local Adaptation coping Strategies of women provides a comprehensive approach towards the study of the variables and therefore a more informed premise upon which decisions and policies with regards to such occurrences can be carried out. The findings offer a factual and evidence based knowledge to the public and various organizations, including the government of the imperatives for their roles and contributions with regards to the welfare, security and wellbeing of the flood victims during their time of crises. This is based on the extent to which the study provides evidence of the women's capacity to recover quickly and stabilize due to the resilience in applying traditional coping strategies in coping with the flood disaster. Planting of flood resistant crops and trees, Traditional storage system, Construction of make-shift platforms and bridges and the use of Indigenous weather warning systems are some of the traditional adaptation coping strategies adopted by women in dealing with the flood incidence in the study area. These strengthen the works of Wamler (2007), UNFCCC (2004), Douglas (2008), and position that victims of flood disasters build their furniture or raise their furniture in order to avoid water touching them. They also use water resistant materials to rebuild and fortify their broken down houses. This is also in addition to the use of sand bags which are laid around the neighbourhoods and houses, to enable people move about again.

Although coping mechanisms adopted by women usually comprised of the following strategies, namely: the relocation to a new geographical area and the adoption of makeshift structures like bridges in order to get to their places of economic activities that were partially affected by the flood and also the engagement in menial jobs like working in farms as labourers in the communities where they relocated to, the belief is that women prefer to return to their previous forms of economic activities as the process of acquiring new skills or entering new markets was rather rigorous and risky for them. Findings of this study also resonates Dike (2012) study that women in the coastal areas for instance try to cope with disasters like flood with their traditional knowledge and art. Women make their houses more resilient to disasters with locally available resources like straws, bamboo poles (sticks), to increase the height of their house foundations and sheds (huts), which helps to protect goats and poultry from flood. He added 
that because women control their homestead-based livelihoods, livestocks, seeds, fisheries trees, animal fodder etc., they play a very significant role in food preservation. One of the traditional ways of coping is the construction of mud-stoves for use in cooking and drying food and for preservation.

\section{References:-}

1. Abams, T. K. (2014). State of Erosion and Flooding in the Niger Delta. Report prepared for the World Bank.

2. Agomoh, M. J. (2017) Indigenous knowledge system and environmental conservation practice in Umuahia South Local Government Area, Abia State. Ph.D Thesis, School of Graduate studies, University of Port Harcourt, Nigeria.

3. Alani, K. (2012). Women, Social Cohesion and Resilience in Conflict Environment. Owerri, Springfield.

4. Amadi, L. (2013). Climate change, peasantry and rural food production decline in the Niger Delta Region: A case of the 2012 flood disaster. Journal of Agriculture and crop research vol 1(6) pp 94-103.

5. Askew, A.J. (2009).Water in the International Decade for Natural Disaster Reduction. IAHS Publication No.239.

6. Cunningham W.P., Cunningham, M.A.,(2006).Principles of Environmental Science, Inquiry and Applications Published by McGraw Hill, New York.

7. Durotoye, B. (2013). Geo-environmental Constraints in the Development of the Niger Delta Area of Nigeria. Lagos: Friedrich Ebert Foundation

8. Enarson, K. (2001). Reconciling Gender Perspectives in Flood Ravaged Communities. Journal of Social Resilience, Vol. 2, No.1 pp102-124

9. Fadahunsi, O. (2013). Social Resilience in Natural Disaster Scenarios. London, Routledge.

10. Huraera, J., Adriana, A., -Cassidy, J. (2010): Built-in Resilence: Learning from Grassroots coping strategies to climate variability. Retrieved from worldbank.org

11. Kwilecki, S. (2004). "Religion and coping: A contribution from Religious studies", journal for the scientific study of religion, 43(4), 477-489.

12. Laughhin, G., Kalma, J. (2000). Frost Risk Mapping for Landscape Planning: A Methodology International Journal of Theoretical and Applied Climatology, Vol. 42, pp. 41-51.

13. Levine, M. (2013): The Promotion of Cooperatives, ILO Cooperative Branch. Retrieved fromwww.ica.coop/europe/ra2002/speech

14. Mumuni, A. (2013). Natural Disaster in Northern Nigeria. Katsina, Kazimi Publications.

15. Nabegu, A. (2014). Analysis of Vulnerability to Flood Disaster in Kano State, Nigeria. Greener Journal of Physical Sciences. Vol. 4, No.2, pp. 022-029, March 2014.

16. Nabeu, A. B. (2014) Analysis of Vulnerability to Flood Disaster in Kano State, Nigeria.Greener Journal of Physical Sciences, Vol. 4 (2), pp. 022-029.

17. Norris, F. (2008). Community Resilience as a Metaphor, Theory, Set of Capacities and Strategies for Disaster Readiness. American Journal of Community Psychology 41 (2): 127-50.

18. Odufuwa B. O. , Adedeji O. H., Oladesu J. O. \& Bongwa A. (2012) Floods of Fury in Nigerian Cities. Journal of Sustainable Development; Vol. 5, No. 7.

19. Olukolade, D. (2012). Flood Disaster and Vulnerability in the Niger Delta Region. Port Harcourt, EMHAI.

20. Oriola, O. (2012). Strategies for Combating Urban Flooding in Developing Countries: A Case Study from Ondo. The Environmental Vol. 14. No. 1,pp. 57-62.

21. Tearfund, D. (2010). One disaster too many: Why Thousands are Dying Needlessly Each Year in Preventable Disasters. A briefing for the World Conference on Disaster Reduction, Kobe, Japan.

22. Tylor, T.R, Kamarch, T.W, Shiffman, S. (2004). Validation of the Detroit area study discrimination scale in a community sample of older African American adults: The Pittsburgh Healthy Heart Project. International Journal of Behavioural medicine, 11(2), 84-94.

23. Ugwu, I. L. \& Ugwu, D. I (2013) Gender, Flood and mental Health: the way forward. International Journal of Asian Social Science, 2013, 3(4):1030-1042.

24. UNICEF (2010).Cool Facts and Tips on flooding, Retrieved from www.unicef.org/appeals/css.UNICEF_Nigeria_Sahel

25. Wamsler, C. (2007). "Bridging the gaps: stakeholder-based strategies for risk reduction and financing for the urban poor" Environment and urbanization 19(1):15-42

26. Wisner B., Blaikie, P.M., Cannon, T., Davis, I. (2004). At Risk Natural Hazards, People's Vulnerability and Disaster, Routledge, London.

27. World Bank (2013).World Natural Disaster Outlook. The World Bank Publication. Retrieved from www.euro.who.int>publications> what are the human health implications of flooding and the strategies to reduce them?

28. Yasui, E. (2007). Community Vulnerability and Capacity in Post Disaster Recovery: The Cases of Mano and Mikura Neighborhoods in the Wake of the 1995 Kobe Earthquake. University of British Columbia. 